\title{
Trifecta of Success for Reducing Commodity-Driven Deforestation: Assessing the Intersection of REDD+ Programs, Jurisdictional Approaches, and Private Sector Commitments
}

\author{
Peter Umunay ${ }^{1}\left(\right.$, Breanna Lujan ${ }^{2}$, Christopher Meyer ${ }^{2, *}$ and Josefina Cobián ${ }^{1}$ \\ 1 School of Forestry and Environmental Studies, Yale University, New Haven, CT 06511, USA; \\ peter.umunay@yale.edu (P.U.); josefina.cobian@yale.edu (J.C.) \\ 2 Environmental Defense Fund, New York, NY 10010, USA; blujan@edf.org \\ * Correspondence: cmeyer@edf.org; Tel.: +1-202-412-5463
}

Received: 15 August 2018; Accepted: 29 September 2018; Published: 2 October 2018

\begin{abstract}
To date, numerous public- and private-sector efforts, commitments, and initiatives to reduce commodity-driven deforestation have emerged. In and of themselves, these elements-namely REDD+ programs, jurisdictional approaches (JAs), and private sector commitments-are necessary, but they are not sufficient to reduce deforestation. When operating together, however, these efforts have the potential to significantly reduce commodity-driven deforestation. This research aimed to determine whether and where REDD+ programs, JAs, and private sector commitments overlap in what are termed "trifecta jurisdictions". Considering that each element possesses features that can enhance and complement those of the others, the authors hypothesized that-but did not ascertain whether-trifecta jurisdictions present the greatest potential to reduce commodity-driven deforestation. A total of 13 trifecta jurisdictions and six bifecta jurisdictions-where two of the three elements are present-were identified by: compiling a dataset of REDD+ programs, JAs, and private sector commitments; evaluating all potential options against established criteria; and categorizing them according to trifecta or bifecta jurisdiction status. The fact that a majority of trifecta and bifecta jurisdictions are located in countries with the most tropical tree cover loss is also significant in that it highlights the presence of these elements where most needed, and how high deforestation rates might be attracting REDD+ program, JA, and private sector commitment activities. Although many of the REDD+ programs, JAs, and private sector commitments are relatively nascent and their ability to collectively reduce deforestation is not yet clearly evident, this article posited that synergistic potential is greatest in trifecta and bifecta jurisdictions and that efforts should be made to greater align these elements.
\end{abstract}

Keywords: REDD+; jurisdictional approaches; private sector commitments; commodity-driven deforestation; trifecta jurisdictions; supply chains; public-private partnerships

\section{Introduction}

In the lead-up to 2020 - a year that marks the deadline for many companies to meet the deforestation and sustainability goals to which they have committed-it is critical for key government and private-sector entities to begin implementing solutions that will prove most effective for combating deforestation resulting from the production of key commodities like soy, cattle, timber and pulp, palm oil, and cocoa [1,2]. Commercial agriculture in tropical forest countries is known to be the driver of $40 \%$ of deforestation and continues to be a driving force of large-scale deforestation [3,4]. In fact, tree cover loss in the tropics has been rising steadily over the past 17 years. According to recent 
Global Forest Watch data, 2017 was the second-worst year on record for tropical forest loss; the tropics alone experienced 15.8 million hectares of tree cover loss that year, an area the size of Bangladesh [5]. Historically, the private sector has approached solving deforestation one supply chain at a time. In light of evident limitations of certification systems (such as the Roundtable on Sustainable Palm Oil and the Forest Stewardship Council) and other approaches that have been used to reduce commodity-driven deforestation, the adoption and evolution of REDD+ as a government driven process leading to results-based payments has begun facilitating the shift of focus away from supply chain-specific approaches, and toward the development and implementation of jurisdictional approaches (JAs) [6,7]. JAs, which will be discussed further in Section 2.3, are integrated, multi-stakeholder planning initiatives at the landscape level that are aligned with subnational or national political jurisdictions to facilitate sustainable economic development and advance environmental commitments to reducing commodity-driven deforestation [8]. A trend seems to be emerging in which government, the private sector, non-governmental organization (NGO) actors, and other stakeholders involved with tackling commodity-driven deforestation are increasingly exploring JAs as potential avenues to overcome the shortcomings of discrete approaches to curb deforestation [9].

Jurisdictional approaches, alongside REDD+ programs and private sector commitments, number among the most promising tools to eliminate commodity-driven deforestation. It should be noted that, while some believe that JAs represent a combined form of REDD+ programs and private sector commitments, in this analysis each of these elements is distinct, as described below:

- $\quad$ REDD+ programs: These programs are governed at the provincial or national jurisdictional (not project) levels, focus on results-based payments for verified carbon sequestration, emphasize public policy, and address deforestation generally (not just commodity-deforestation).

- Jurisdictional approaches: JAs focus more on the role of public-private partnerships for reducing commodity-driven deforestation and avoiding economic and deforestation leakages.

- Private sector commitments: These pledges are made in various forms-such as zero deforestation commitments and certification standards-by individual companies to reduce deforestation in their supply chains.

Facing mounting pressure to broadly and effectively reduce commodity-driven deforestation, governments and companies alike are striving to identify the most promising solutions. Given that in and of themselves, these elements are not sufficient to reduce commodity-driven deforestation at scale, REDD+ programs, JAs, and private sector commitments need to operate in conjunction to significantly reduce commodity-driven deforestation; each element has the potential to support, complement, and enhance the others to ensure their medium to long term success [10,11]. Pursuing this line of thinking, this paper explores the questions: How many current REDD+ programs (subnational and above), JA initiatives, and private sector commitments overlap in the same jurisdictions? How can these jurisdictions be characterized? This article hypothesizes that efforts to reduce and eliminate commodity-driven deforestation at a landscape level will be most successful in jurisdictions where all three elements-REDD+ programs, JAs, and private sector commitments-are in place; these jurisdictions are referred to as "trifecta jurisdictions" (Figure 1).

This article begins with providing an overview of the linkages between REDD+ and commodity-driven deforestation, the successes and limitations of private sector approaches to reduce commodity-driven deforestation, and the characteristics of JAs. The next section describes the methodology of the analysis, followed by a discussion of the findings. More detailed descriptions of the REDD+ programs, JAs, and private sector commitments analyzed in this article can be found in the supplementary materials. The concluding section provides insights into the relevance of the results and how they can be used to advance action to reduce commodity-driven deforestation in key jurisdictions. 


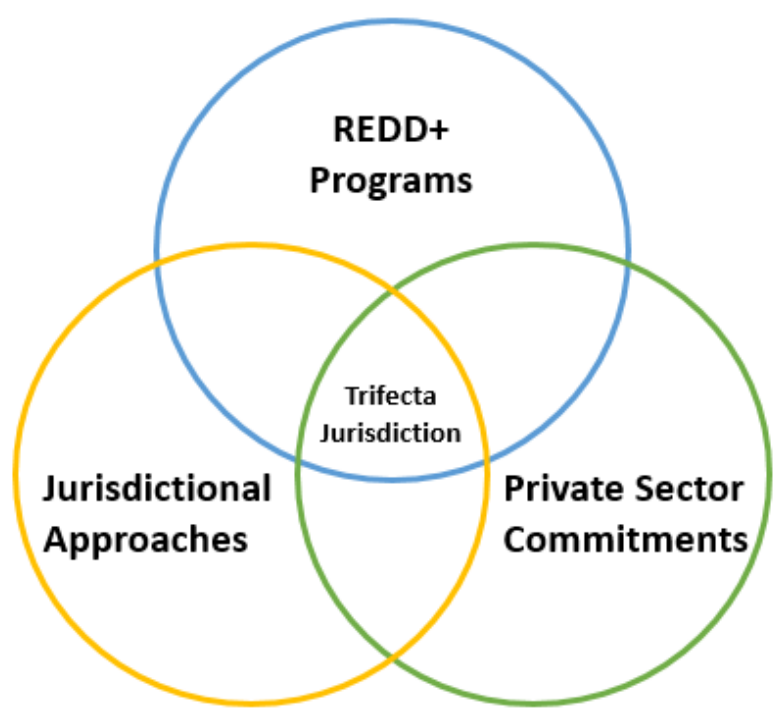

Figure 1. Elements of a trifecta jurisdiction.

\section{Background}

\subsection{REDD+ Programs}

The linkage between commodity production and deforestation began before REDD+ was formally introduced in the United Nations Framework Convention on Climate Change (UNFCCC) negotiation process in 2005 [12]. Previous to the entrance of what is now jurisdictional REDD+ into the UNFCCC process, project level REDD+ started as early as 1997 with the Noel Kempf Mercado Climate Action project in Bolivia [13]. Initial thoughts about applying REDD+ as a tool to address deforestation in supply chains revolved around disagreement at the global level over two questions posed by developing countries: (1) Why should they not be allowed to clear forest for development purposes, when a portion of forest clearing was done to plant commodities to meet growing demand from global supply chains? (2) And if they were not going to clear forest, who was going to compensate them for the opportunity cost? [14].

After eight years, UNFCCC negotiations on REDD+ culminated in the Warsaw Framework for REDD+ (WFR). The WFR provides an overarching framework and methodological guidance for REDD+ implementation and payment for results at the federal level. Because of concerns about deforestation leakage from smaller project type REDD+ into neighboring areas-such as soy-related deforestation leakage from the Brazilian Amazon biome to the Cerrado biome for example-UNFCCC negotiators at COP16 defined the scale of REDD+ to be at the national level and only subnational level in the interim [15]. The jurisdictional or government-level scale of the WFR ensures that REDD+ programs are the focus of national strategies, rather than an amalgamation of distinct projects. The WFR requires that National REDD+ Strategies describe how the drivers of deforestation will be addressed and encourages all countries, organizations, and the private sector to take action to reduce the drivers [16]. However, no explicit type of demand-side actions to address the drivers are required of developed countries or of consumers of deforestation driving commodities [16].

To better tackle the specific and unique nature of commodity-driven deforestation, many initiatives are now exploring how to link REDD+ programs to other initiatives to reduce commodity-driven deforestation. For example, many multilateral REDD+ programs, such as the Forest Carbon Partnership Facility (FCPF), Forest Investment Program (FIP), and the UN-REDD Program, created to help countries prepare for and implement REDD+, have supported efforts to address the commodity drivers of deforestation in REDD+ countries [17-19]. Additionally, platforms like the Tropical Forest Alliance 2020 (TFA 2020), Consumer Goods Forum (CGF), and New York Declaration on Forests (NYDF) came to the fore to help catalyze linkages between public and private sector actors seeking to reduce 
deforestation [1,2,20]. Finally, the Norwegian International Climate and Forest Initiative (NICFI)—one of the major REDD+ donors-supported several NGOs to study "Commodity Supply Chain Initiatives of Relevance to REDD+" between 2013 and 2015 [21].

Although REDD+ programs are demonstrating progress, REDD+ is still considered to be "a great idea, but hardly tried" by many [22,23]. The need to comply with stringent donor or government criteria has delayed the implementation of REDD+ programs, as has the ability to overcome vested interests related to business-as-usual [22,24]. REDD+ programs must also tackle other difficult governance challenges that accompany improving land tenure and benefit distribution, which can be complicated by local circumstances [25]. Lastly, the ability of REDD+ to effectively address the underlying drivers of deforestation can be hindered by the unique and specific nature of deforestation drivers, and the broad reach of potential trade impacts that such actions might have [26].

\subsection{Private Sector Commodity Supply Chain Initiatives}

As of June 2018, 473 companies globally have committed to curbing deforestation in supply chains linked to palm oil, soy, timber and pulp, and cattle [27]. Such commitments have taken various forms, including targets related to purchasing certified products, supply chain traceability, moratoria on areas or suppliers linked to deforestation, certification schemes and sectoral standards, and other goals to improve sustainable management or reduce deforestation. The surge in private sector commitments is helping elevate the importance of forests, forge linkages between key stakeholders throughout supply chains, and focus attention on key deforestation drivers [28]. The certification approach, in particular, including the Forest Stewardship Council (FSC), Roundtable on Sustainable Palm Oil (RSPO), and the Soy Moratorium, continues to serve as a primary tool of many private sector commitments and has demonstrated mild success in curbing deforestation by setting a precedent for achieving traceability, producing responsibly, and establishing important platforms to discuss and determine best management practices [29-31].

Despite these benefits, there is no clear evidence that these private sector initiatives are having their intended impacts. The many shortcomings, specifically of certification systems, have become particularly evident [32]. Various socio-economic and environmental limitations such as economic leakage, low and selective adoption, poor forest governance, minimal market uptake, high expenses for small holders, lack of government buy in, and unintended social consequences all undermine the potential of private interventions to aggregate towards meeting broader aspirational goals to reduce commodity-driven deforestation [6]. Moreover, limited geographical coverage induces geographical leakage effects, while the focus on specific commodities does not allow for a comprehensive approach to land use changes and precludes potential indirect feedback effects [6]. Additionally, continued demand for conventional cheaper commodities might undermine supply chain action. Regarding certification systems, the limitations of this approach have also become more apparent. For example, despite the rapid expansion of FSC certification, evidence suggests that the certification system has had very little positive impact on deforestation [33]. The success of RSPO, on the other hand, has been challenged by lax implementation and weak commitments to sustainable palm oil production [34]. The Soy Moratorium's success has also been questioned due to potential leakage of soy-related deforestation from the Amazon biome to the Cerrado Biome [35]. Overall, there are myriad uncoordinated corporate initiatives with different objectives, measures, and timelines whose implementation is hardly monitored [6]. The effectiveness of such a highly fragmented approach to halting deforestation is questionable at the very least.

\subsection{Jurisdictional Approaches}

As noted, there are various public and private platforms, programs, and initiatives that have ushered in a wave of commitments to halt deforestation. However, the lack of coordinated and integrated strategies has made it challenging to meet demands for agricultural products without further deforestation and economic leakage. While individual company, NGO, and government 
actions have helped pave the way towards curbing commodity-driven deforestation, lasting and significant progress will likely require implementation at scale through jurisdictional-level planning and cooperation among key stakeholders [36].

The JA aims to do just that by aligning and coordinating the conservation, supply chain sustainability, and green development interests and actions of various stakeholders within a jurisdiction-a country or a politically defined area (such as a state or province) with defined governance [37]. The JA is a more inclusive and comprehensive solution than project- or supply chain-specific strategies that focuses on tackling deforestation from all angles. This government-led, multi-stakeholder process, which includes companies, producers, purchasers, civil society, local communities, and other local stakeholders, facilitates deforestation reduction across entire landscapes [9]. The JA focus on government is fundamental to the success of this strategy. Recognizing the value and importance of government involvement and action at scale, companies are beginning to consider JAs in order to meet their supply chain sustainability commitments.

By engaging key public and private actors, JAs combine strong governance and policy interventions with supply chain efforts aimed at reducing commodity-driven deforestation [32]. Through aligning multistakeholder goals, JAs present opportunities for these actors to work together in public-private partnerships to address issues that could undermine supply chain efforts aimed at tackling deforestation such as leakage, which means deforestation problems are simply shifted to other places, commodities, or ecosystems [32]. Furthermore, the results generated by JAs can easily be linked to results-based payments for REDD+, and can benefit from finance for phases 1 (readiness) and 2 (implementation) of REDD+. The scalability of JAs, and knowledge and experience sharing that accompanies collaboration at scale, helps ensure widespread and potentially long-term impacts.

Despite the potential of JAs to contribute to efforts to reduce deforestation, there are several challenges that could hinder their success. In order for JAs to be effective, strong governance needs to be in place at the appropriate scale [36]. Additionally, not only do all stakeholders involved need to coordinate and align their goals and efforts, they also need to be inclusive of all potential actors that could impact or be impacted by JA performance, such as those involved with REDD+ programs [38]. Another potential issue is that, by operating at a jurisdictional scale, recognition of good actors and identification of non-compliant actors-who may simply shift operations outside of the jurisdiction in question so as to continue deforesting-may be challenging.

\section{Trifecta Jurisdiction Analysis Methodology}

As demonstrated in the previous section, REDD+ programs, JAs, and private sector commitments face many challenges. When combined in trifecta jurisdictions, however, these challenges can be overcome, and the synergies between the three elements can facilitate more effective and lasting commodity-driven deforestation reduction (Figure 2). To answer the questions underpinning this analysis-where do REDD+ programs, JA, and private sector initiatives overlap in the same jurisdiction, and how can these trifecta jurisdictions be characterized —-the trifecta jurisdiction analysis methodology was developed.

The first step of the methodology entailed creating several criteria to ascertain which REDD+ programs, JAs, and private sector commitments qualified for analysis. Then a comprehensive data set of all potential REDD+ programs, JAs, and private sector commitments to be taken into consideration was compiled. These initiatives were then assessed and categorized according to the established criteria to determine which would be eligible for analysis. Finally, eligible REDD+ programs, JAs, and private sector commitments were organized by jurisdiction to determine whether and where these initiatives overlapped in trifecta jurisdictions (Table S1) or bifecta jurisdictions (Table S2), and to identify which areas might be of interest for deeper analysis; more detail about the REDD+ program, JA, and private sector commitment initiatives included in this analysis can be found in the supplementary material. 


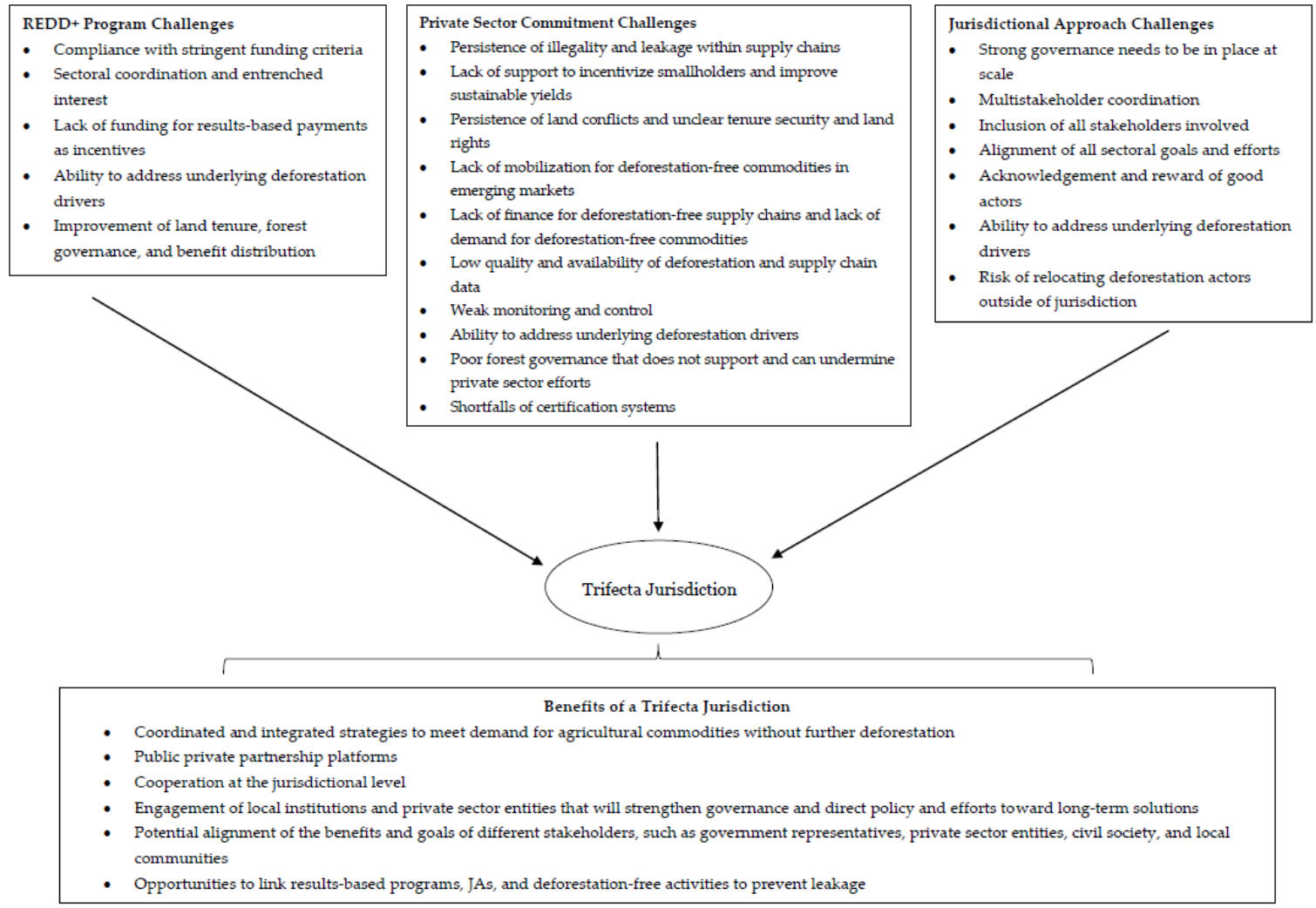

Figure 2. Element-specific challenges that can be overcome through collaboration in trifecta jurisdictions and the benefits such alignment can yield.

\subsection{Criteria for the Selection of REDD+ Programs}

Four different criteria were used to determine which national and subnational REDD+ programs were eligible for this analysis. The first criterion reflected whether a country had a UN-REDD national program in place, the second whether a country had made significant progress in multilateral programs such as the $\mathrm{FCPF}$, and the third whether a country had submitted a forest reference emission level/forest reference level (FREL/FRL) to the UNFCCC's Lima Info Hub [23]. These three criteria reflect how far along REDD+ implementation is in various countries. A REDD+ program was deemed eligible for analysis if two of the first three criteria mentioned were met. The fourth criterion reflected whether a subnational jurisdiction is engaged in bilateral REDD+ program agreements, such as the German Development Bank's (KfW) REDD+ Early Movers (REM) Program; those that are were also considered eligible [39].

\subsection{Criteria for the Selection of Jurisdictional Approaches}

As the JA concept continues gaining traction, more and more initiatives at the jurisdictional scale are being developed. To be included in this analysis, jurisdictional approaches needed to prioritize government leadership and involvement. In other words, subnational or national governments had to be involved in the JA from its inception, and continue to play a key role throughout implementation. The second criterion was that a JA needed to revolve around reducing deforestation resulting from the production of one or several of the key commodities of focus: soy, cattle, cocoa, palm oil, or timber and pulp. These commodities were selected due to their impact on deforestation. Lastly, there needed to be documented action or progress demonstrating that each JA was underway. 


\subsection{Criteria for the Selection of Private Sector Commitments}

Although many companies have made commitments to reduce or eliminate deforestation from their supply chains, for this analysis, corporate commitments were only considered if they met three criteria. The first criterion required that company commitments, strategies, or announcements indicating an intent to reduce deforestation, create sustainable supply chains, or source responsibly be published in a publicly accessible way. Second, corporate commitments needed to be tied to one of the key commodities. The last selection criterion referred to information on the geographical location of the action. A simple statement that the action was intended, but without information on where the action was occurring, was not considered sufficient.

\section{Results}

\subsection{Trifecta Jurisdictions}

According to the trifecta analysis, there are a total of 13 trifecta jurisdictions in which all three elements are in place (Table 1). Of those, 12 are at the country level, while one is at the subnational level. Five of the jurisdictions are located in Latin America, six in Africa, and two in Southeast Asia. When comparing trifecta jurisdictions to a list of the top 30 tropical forest countries with the most tree cover loss from 2001 to 2016 (Table A1), 11 of the trifecta jurisdictions are in the top 30. The top five countries on the list (Brazil, Indonesia, Democratic Republic of the Congo, Malaysia, and Paraguay in order) are all trifecta jurisdictions; if Mato Grosso were a country, it would have been ranked fourth on the list. This is an important finding, because it indicates that coordinated efforts are occurring where there is significant deforestation. The fact that trifecta jurisdictions are located in areas with the most tree cover loss could also mean that high deforestation is attracting REDD+ program, JA, and private sector commitment action. This does not indicate, however, the degree to which these elements are aligned; further analysis is needed to ascertain the extent of coordination, as explained in the discussion section.

Table 1. All trifecta jurisdictions, including commodities of focus and geographies of interest.

\begin{tabular}{|c|c|c|c|c|c|c|}
\hline Trifecta Jurisdiction & Cattle & Soy & Palm Oil & Cocoa & Pulp-Timber & Geographies of Interest \\
\hline Brazil & $\checkmark$ & $\checkmark$ & & & & Amazon and Cerrado biomes ${ }^{1}$ \\
\hline Colombia & $\checkmark$ & $\checkmark$ & $\checkmark$ & $\checkmark$ & & Orinoquia \\
\hline Côte d'Ivoire & & & $\checkmark$ & $\checkmark$ & $\checkmark$ & Southwest and Tai Regions \\
\hline Dominican Republic & & & & $\checkmark$ & & Country \\
\hline Gabon & & & $\checkmark$ & & & Country \\
\hline Ghana & & & $\checkmark$ & $\checkmark$ & & Brong-Ahafo and Western Region \\
\hline Mato Grosso, Brazil & $\checkmark$ & $\checkmark$ & & & & Mato Grosso \\
\hline Nigeria & & & $\boldsymbol{v}$ & & & Country \\
\hline Paraguay & $\checkmark$ & $\boldsymbol{\nu}$ & & & & Atlantic Forest region \\
\hline Republic of Congo & & & $\boldsymbol{v}$ & $\checkmark$ & & Country \\
\hline Total & 5 & 5 & 9 & 7 & 2 & - \\
\hline
\end{tabular}

${ }^{1}$ Although the Amazon and Cerrado biomes include Mato Grosso, the state is treated as an individual jurisdiction because of progress specific to Mato Grosso.

In terms of commodities, of the 13 trifecta jurisdictions, nine include explicit private sector commitments or JAs with a focus on palm oil, and are underway across the world. Cattle, the largest source of commodity-driven deforestation and one that is traded less globally comparatively, is being addressed in five jurisdictions (two of which overlap in the Brazilian Amazon biome, which extends into Mato Grosso) [40]. Soy efforts are also focused in Latin America, where there are four jurisdictions of note (two in Brazil, one in Paraguay, and one in Colombia). Cocoa was also a focus in seven jurisdictions (four in Africa, one in Asia, and two in Latin America). Of note is that key commodities are being tackled by JAs and private sector initiatives underway in the five countries experiencing the most forest cover loss. Palm oil is the focus in Indonesia, the Democratic Republic of the Congo, 
and Malaysia; cattle and soy in Brazil and Paraguay; and timber and pulp in the Democratic Republic of the Congo and Côte d'Ivoire.

\subsection{Bifecta Jurisdictions}

Those jurisdictions in which two of the three elements are present are known as bifecta jurisdictions (See Table 2). Of the six bifecta jurisdictions identified in this analysis, one is subnational and five are national. REDD+ and JA initiatives are underway in all six of the bifecta jurisdictions. There are no geographically specific private sector commitments present in any of the bifecta jurisdictions, however.

Table 2. All bifecta jurisdictions, including commodities of focus and geographies of interest ${ }^{1}$.

\begin{tabular}{cccccc}
\hline Bifecta Jurisdiction & Cattle & Soy & Palm Oil & Cocoa & Geographies of Interest \\
\hline Acre, Brazil & $\boldsymbol{V}$ & & & & Acre \\
Ecuador & $\boldsymbol{V}$ & $\boldsymbol{V}$ & & Country \\
Mexico & $\boldsymbol{V}$ & & $\boldsymbol{V}$ & Country \\
Nepal & $\boldsymbol{V}$ & & $\boldsymbol{V}$ & Terai Arc Landscape \\
Peru & $\boldsymbol{V}$ & & & $\begin{array}{c}\text { Eastern Valley } \\
\text { Zambia }\end{array}$ \\
Total & 5 & 1 & 3 & 2 & - \\
\hline
\end{tabular}

\footnotetext{
${ }^{1}$ As stated above, all bifecta jurisdictions listed have a REDD+ program and JA in place, but lack geographically
} specific private sector commitments.

Considering the relevance of the bifecta jurisdictions in the list of top 30 countries with forest cover loss from 2001 to 2016, five of the six bifecta jurisdictions are represented; Nepal was the only country that did not make the list. If the Brazilian state of Acre were a country, the sub-national jurisdiction would have ranked 26th on the list. Regarding commodities driving deforestation, cattle was a focus in five of the jurisdictions (Ecuador, Mexico, Nepal, Peru, and Acre), with palm following in three of the jurisdictions (Ecuador, Mexico, and Peru). Soy (Zambia) and cocoa (Peru and Ecuador) were also covered to lesser extents.

\section{Discussion}

The trifecta jurisdiction concept is nascent, considering that implementation of many REDD+ programs, JAs, and private sector commitments has only just begun. As such, at this stage it is difficult to determine the extent to which these elements are aligning; this analysis aimed to determine where the three elements are occurring so as to flag areas of interest and importance, but did not set out to ascertain the extent or nature of any alignment. Further clarity about the potential success of trifecta jurisdictions is essential, however, considering the limitations of each distinct trifecta jurisdiction element. Analyzing the production of export commodities, the extent of deforestation due to the volume of commodity production, and the presence of large corporates active in export production in trifecta jurisdictions could shed light on how the elements are aligning and the potential impact of this alignment.

Our results indicate that of the 19 trifecta and bifecta jurisdictions, 16 of the countries represented are found in the top 30 tree cover loss list. More interestingly, trifecta jurisdictions are located in the top five tree cover loss countries. These results reinforce our assumption that much of the REDD+ program, $\mathrm{JA}$, and/or private sector work is occurring in areas where deforestation is most prevalent and that, therefore, there is a need to continue encouraging public and private entities to work together to tackle commodity-driven deforestation. An area that demonstrates the potential of trifecta jurisdictions to curb commodity-driven deforestation is Mato Grosso, Brazil (a trifecta jurisdiction); see Box 1 for a more in-depth explanation of what is occurring in this trifecta jurisdiction. Although this article posits that trifecta jurisdictions are the most likely to succeed in reducing, and eventually eliminating, commodity-driven deforestation, future analysis is needed to determine the validity of this hypothesis. 
Box 1. A description of the trifecta elements in Mato Grosso, Brazil.

\begin{abstract}
Box 1: Mato Grosso, Brazil-A Trifecta Jurisdiction
Mato Grosso, Brazil is one of the jurisdictions where a REDD+ program, a JA, and pri-vate sector commitments overlap; in other words, Mato Grosso is a trifecta jurisdiction. With regards to REDD+, in addition to adhering to the national REDD+ strategy and FREL data that the Brazilian government submitted to the UNFCCC REDD+ platform, the Mato Grosso state government passed a law to create a state REDD+ system in 2013 [41,42]. Additionally, Mato Grosso signed a results-based payment agreement with the REM pro-gram in 2017 [43]. Mato Grosso has also been a pioneer when it comes to JAs. In 2015, the governor of Mato Grosso launched the Produce, Conserve, Include strategy (PCI), a state government-led multistakeholder strategy that aims to keep $6 \mathrm{GtCO}_{2}$ emissions from forests out of the at-mosphere by 2030 [44]. To contribute to climate change mitigation and adaptation, the PCI aims to restore 6 million ha of degraded pastures, reduce deforestation by $90 \%$, increase agricultural production, and include smallholders and indigenous communities. Many private sector entities have been active in the PCI. Companies such as Amaggi, Lou-is-Dreyfus, and JBS, support Mato Grosso's PCI strategy through engaging in sustainable sourcing agreements, supporting the development of technical capacity, promoting sus-tainable practices to increase productivity, and providing conservation and financial bene-fits to ranchers. Amaggi, for example, has been actively working with the PCI governance entities to develop a strategic forest restoration plan for Mato Grosso that is in line with both state and private sector goals [45].

Compared to the neighboring state of Pará, which faces similar drivers of deforesta-tion and had a similar deforestation trend, Mato Grosso seems to have gained traction in reducing deforestation while increasing agricultural production. Using 2015 as a starting point for when the PCI, private sector commitments, and REDD+ programs were all in place-or when the trifecta elements were all in effect-it is evident that Mato Grosso has realized a reduction in its annual deforestation rate by $2.5 \%$ (deforestation rates totaled $2153 \mathrm{~km}^{2}$ in 2015 , and decreased to $1561 \mathrm{~km}^{2}$ in 2017), while deforestation rates in the neighboring state of Pará jumped from $2153 \mathrm{~km}^{2}$ in 2015 to $2433 \mathrm{~km}^{2}$ in 2017; an increase of about 13\% (Figure A1) [46]. While too early to state that the difference in deforestation reduction performance between Mato Grosso and Pará equates to proof that trifecta juris-dictions are more successful in terms of reducing commodity-driven deforestation, it does show a promising trend toward a greater decrease of deforestation in one of the trifecta jurisdictions identified as likely to perform in the future.
\end{abstract}

Data demonstrating the collective impacts of these elements on commodity-driven defor-estation in trifecta jurisdictions is also limited at this stage. Although it is difficult to pinpoint how much of a role the synergies between trifecta elements have contributed to or could contrib-ute to commodity-driven deforestation reduction, in areas where private governance systems coordinate and integrate efforts with public governance and involve all local stakeholders within the jurisdiction, the likelihood of decreasing deforestation at a large scale is greater. Findings from Heilmayr and Lambin support our hypothesis and indicate that governance regimes with greater collaboration between environmental and industry stakeholders can achieve better environmen-tal outcomes [47].

\title{
6. Conclusions
}

The purpose of this analysis was to determine whether and where REDD+ program, JA, and private sector initiatives overlap in trifecta and bifecta jurisdictions, and to discuss what potential impact this overlap could have on reducing commodity-driven deforestation at a broad scale. The underlying hypothesis driving this analysis is that, because REDD+ program, JA, and private sector efforts each possess features that can enhance and complement those of the other initiatives, jurisdictions with all three elements in place will perform the best at reducing commodity-driven deforestation over the medium to long term. More analysis will be needed in the future, however, to determine the extent to which this hypothesis is valid. Additionally, analyses could be done on how different initiatives complement each other so as to understand the intricate dynamics of this collaboration, and to identify any other elements that might need to be in place to further catalyze performance. Such analyses would be invaluable in the areas of interest-trifecta and bifecta jurisdictions-flagged in this article.

This analysis identified 13 jurisdictions where all three of the initiatives believed to be essential in combating commodity-driven deforestation are underway. By identifying where these "trifecta 
jurisdictions" are located, this analysis has highlighted those areas we hypothesize to have the most potential for effectively curbing commodity-driven deforestation. Although it is too early to tell how these jurisdictions are performing in terms of reducing commodity-driven deforestation, monitoring whether the alignment of the trifecta elements is having an impact will be helpful in determining the most effective strategies for reducing commodity-driven deforestation.

As time passes, and more action is taken to curb commodity-driven deforestation, the trifecta elements will continue catalyzing and complementing one another. Private sector actors, government members, NGOs, producers, traditional communities, and other local stakeholders need to realize that reducing commodity-driven deforestation requires collaboration across sectors and at a broad scale. Trifecta jurisdictions could facilitate that coordination. By determining where REDD+ programs, JAs, and private sector commitments are overlapping and discussing the potential significance of this alignment, this article aims to further discussions regarding how to most effectively and efficiently reduce commodity-driven deforestation.

Supplementary Materials: The following are available online at http:/ /www.mdpi.com/1999-4907/9/10/609/s1, Table S1: A comprehensive list of all trifecta jurisdictions identified in this analysis, Table S2: A comprehensive list of all bifecta jurisdictions identified in this analysis.

Author Contributions: Conceptualization, C.M., B.L. and P.U.; Methodology, C.M., B.L. and P.U.; Data curation B.L., J.C., P.U. and C.M.; Formal Analysis, C.M., B.L. and P.U.; Writing-Original Draft Preparation, C.M., B.L. and P.U.; Writing-Review \& Editing, B.L., C.M., P.U.; Visualization, B.L., C.M., P.U. and J.C.

Funding: This research was supported by Norway's International Climate and Forest Initiative (NICFI).

Conflicts of Interest: The authors declare no conflicts of interest.

\section{Appendix A}

Table A1. Top 30 countries with the most tropical forest loss between 2001 and 2016.

\begin{tabular}{|c|c|c|c|}
\hline Country & Ranking & Trifecta & Bifecta \\
\hline Brazil & 1 & $\checkmark$ & \\
\hline Indonesia & 2 & $\checkmark$ & \\
\hline $\begin{array}{c}\text { Democratic Republic of } \\
\text { the Congo }\end{array}$ & 3 & $\checkmark$ & \\
\hline Brazil_Mato Grosso & 4 & $v$ & \\
\hline Malaysia & 4 & $v$ & \\
\hline Paraguay & 5 & $v$ & \\
\hline Bolivia & 6 & & \\
\hline Colombia & 7 & $\boldsymbol{v}$ & \\
\hline Mexico & 8 & & $v$ \\
\hline Myanmar & 9 & & \\
\hline Madagascar & 10 & & \\
\hline Mozambique & 11 & & \\
\hline Peru & 12 & & $\checkmark$ \\
\hline Laos & 13 & & \\
\hline Angola & 14 & & \\
\hline Vietnam & 15 & & \\
\hline Côte d'Ivoire & 16 & $\boldsymbol{v}$ & \\
\hline Tanzania & 17 & & \\
\hline Venezuela & 18 & & \\
\hline Thailand & 19 & & \\
\hline India & 20 & & \\
\hline Zambia & 21 & & $\boldsymbol{v}$ \\
\hline Papua New Guinea & 22 & & \\
\hline Brazil_Acre & 22 & & $\checkmark$ \\
\hline Cameroon & 23 & & \\
\hline Ghana & 24 & $\boldsymbol{v}$ & \\
\hline Ecuador & 25 & & $\boldsymbol{v}$ \\
\hline Central African Republic & 26 & & \\
\hline Republic of Congo & 27 & $v$ & \\
\hline Nigeria & 28 & $\checkmark$ & \\
\hline Gabon & 29 & $v$ & \\
\hline Ethiopia & 30 & & \\
\hline
\end{tabular}




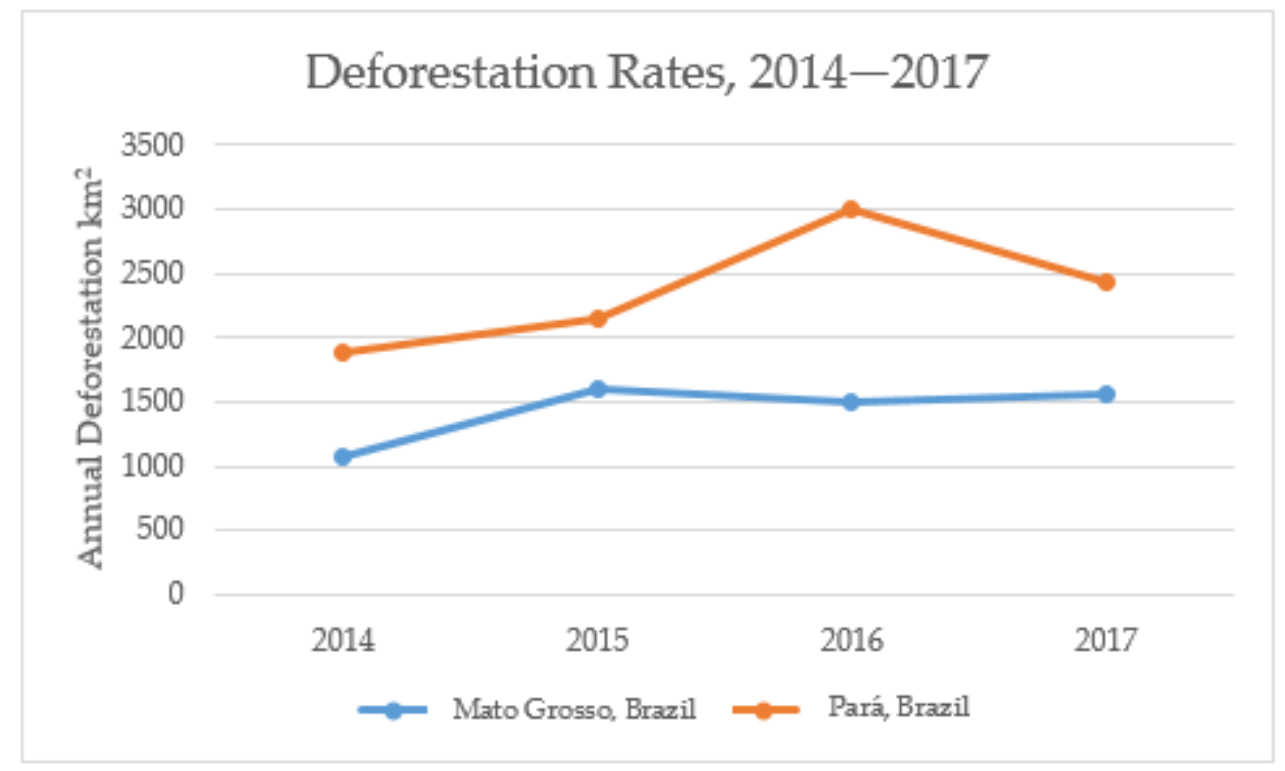

Figure A1. Deforestation rates for Mato Grosso and Pará, Brazil between 2014 and 2017.

\section{References}

1. United Nations Climate Summit. New York Declaration on Forests-Action Agenda. Available online: https:/ / nydfglobalplatform.org/wp-content/uploads/2017/10/NYDF_Action-Agenda.pdf (accessed on 11 September 2018).

2. The Consumer Goods Forum. Deforestation. Available online: https://www.theconsumergoodsforum.com/ initiatives/environmental-sustainability/key-projects/deforestation/ (accessed on 11 September 2018).

3. Seymour, F. Deforestation is Accelerating, Despite Mounting Efforts to Protect Tropical Forests. What Are We Doing Wrong? Available online: https:/ /blog.globalforestwatch.org/data/deforestation-is-acceleratingdespite-mounting-efforts-to-protect-tropical-forests-what-are-we-doing-wrong (accessed on 10 August 2018).

4. Hosonuma, N.; Herold, M.; De Sy, V.; De Fries, R.S.; Brockhaus, M.; Verchot, L.; Angelsen, A.; Romijn, E. An assessment of deforestation and forest degradation drivers in developing countries. Environ. Res. Lett. 2012, 7, 4009. [CrossRef]

5. Weisse, M.; Goldman, E.D. 2017 Was the Second-Worst Year on Record for Tropical Tree Cover Loss. Available online: http:/ / www.wri.org/blog/2018/06/2017-was-second-worst-year-record-tropical-tree-cover-loss (accessed on 10 August 2018).

6. Lambin, E.; Gibbs, H.; Heilmayr, R.; Carlson, K.; Fleck, L.; Garrett, R.; de Waroux, Y.; McDermott, C.; McLaughlin, D.; Newton, P.; et al. The role of supply-chain initiatives in reducing deforestation. Nat. Clim. Chang. 2018, 8, 109-116. [CrossRef]

7. AlphaBeta. Supporting Jurisdictional Leadership in Net Zero Deforestation through Sustainable Value Chains: Opportunities for TFA 2020. Available online: https:/ /www.tfa2020.org/wp-content/uploads/ 2017/04/TFA2020-Supporting-jurisdictional-leadership-in-net-zero-deforestation-Report.pdf. (accessed on 9 September 2018).

8. Wang, M. A Closer Look at Jurisdictional Approaches. Available online: https://www.tfa2020.org/en/ closer-look-jurisdictional-approaches / (accessed on 7 September 2018).

9. Wolosin, M. Jurisdictional Approaches to Zero Deforestation Commodities. Available online: http: / / d2ouvy59p0dg6k.cloudfront.net/downloads/wwf_jurisdictional_approaches_to_zdcs_nov_2016.pdf (accessed on 13 August 2018).

10. Bernstein, S.; Cashore, B. Complex global governance and domestic policies: Four pathways of influence. Int. Aff. 2012, 88, 585-604. [CrossRef]

11. Newton, P.; Agrawal, A.; Wollenberg, L. Enhancing the sustainability of commodity supply chains in tropical forest and agricultural landscapes. Glob. Environ. Chang. 2013, 23, 1761-1772. [CrossRef]

12. Pearce, D.; Barbier, E. Blueprint for a Sustainable Economy; Earthscan Publications Ltd.: London, UK, 2000; ISBN 1853835153. 
13. Holloway, V.; Giandomenico, E. The History of REDD Policy. Available online: https://redd.unfccc.int/ uploads/2_164_redd_20091216_carbon_planet_the_history_of_redd_carbon_planet.pdf (accessed on 21 September 2018).

14. Ingalls, M.L.; Meyfroidt, P.; To, P.X.; Kenney-Lazar, M.; Epprecht, M. The transboundary displacement of deforestation under REDD+: Problematic intersections between the trade of forest-risk commodities and land grabbing in the Mekong region. Glob. Environ. Chang. 2018, 50, 255-267. [CrossRef]

15. Noojipady, P.; Morton, D.C.; Macedo, M.N.; Victoria, D.C.; Huang, C.; Gibbs, H.K.; Bolfe, E.L. Forest carbon emissions from cropland expansion in the Brazilian Cerrado biome. Environ. Res. Lett. 2017, 12, 2. [CrossRef]

16. United Nations Framework Convention on Climate Change. Addressing the Drivers of Deforestation and Forest Degradation. Available online: https://unfccc.int/resource/docs/2013/cop19/eng/10a01.pdf\#page= 43 (accessed on 21 September 2018).

17. Forest Carbon Partnership Facility. Forest Carbon Partnership Facility. Available online: https:// www.forestcarbonpartnership.org/sites /fcp/files/2017/Sep/FCPF_Annual2017_web.pdf (accessed on 9 September 2018).

18. Climate Investment Funds. FIP Operations and Results Report. Available online: https://www. climateinvestmentfunds.org/sites/cif_enc/files / fip_19_3_orr_1.pdf (accessed on 9 September 2018).

19. UN-REDD Programme Fund. 9th Consolidated Annual Progress Report of the UN-REDD Programme Fund. 2018. Available online: https:/ / unredd.net/documents/programme-progress-reports-785/2017-programmeprogress-reports /16895-ninth-consolidated-annual-progress-report-of-the-un-redd-programme-fund-lowresolution.html (accessed on 1 October 2018).

20. Tropical Forest Alliance 2020. Objectives. Available online: https://www.tfa2020.org/en/about-tfa/ objectives / (accessed on 9 September 2018).

21. Norwegian Climate and Forest Initiative (NICFI). Norad/Climate and Forest Initiative Funding Scheme for Civil Society 2013-2015: Guide to the Thematic Priority Areas. Available online: https:/ / www.norad.no/globalassets/ import-2162015-80434-am/www.norad.no-ny/filarkiv/3.-sivsa-2012--- / ffi/guide-to-thematic-areas.pdf (accessed on 9 September 2018).

22. Seymour, F.; Busch, J. Why Forests? Why Now? Brookings Institution Press: Washington, DC, USA, 2016; ISBN 978-1-933286-85-3.

23. United Nations Framework Convention on Climate Change. Lima REDD+ Information Hub. Available online: https: / / redd.unfccc.int/info-hub.html (accessed on 11 September 2018).

24. Brockhaus, M.; Korhonen-Kurki, K.; Sehring, J.; Di Gregorio, M.; Assembe-Mvondo, S.; Babon, A.; Bekele, M.; Gebara, M.F.; Khatri, D.B.; Kambire, H.; et al. REDD+ transformational change and the promise of performance-based payments: A qualitative comparative analysis. Clim. Policy 2017, 17, 708-730. [CrossRef]

25. Jodoin, S. Forest Preservation in a Changing Climate: REDD+ and Indigenous and Community Rights in Indonesia and Tanzania; Cambridge University Press: Cambridge, UK, 2017; ISBN 978-107-18900-3.

26. La Viña, A.G.M.; de Leon, A. Two Global Challenges, One Solution: International Cooperation to Combat Climate Change and Tropical Deforestation. Available online: https://www.cgdev.org/sites/default/ files/CGD-Climate-Forest-Paper-Series-14-LaVina-DeLeon-International-Cooperation_0.pdf (accessed on 10 August 2018).

27. Haupt., F.; Bakhtary, H.; Schulte, I.; Galt, H.; Streck, C. Progress on Corporate Commitments and their Implementation. Available online: http:/ /www.tfa2020.org/wp-content/uploads/2018/06/Progress-onCorporate-Commitments-and-their-Implementation.pdf (accessed on 26 June 2018).

28. Chagas, T.; Streck, C.; Galt, H.; Zwick, S.; Schulte, I.; Kroeger, A.; Thompson, A. Impacts of Supply Chain Commitments on the Forest Frontier. Available online: https:/ /www.tfa2020.org/wp-content/uploads / 2018/06/Impacts-of-Supply-Chain-Commitments-on-the-Forest-Frontier.pdf (accessed on 6 June 2018).

29. Forest Stewardship Council. Available online: https:/ / us.fsc.org/en-us (accessed on 10 September 2018).

30. Roundtable on Sustainable Palm Oil (RSPO). Available online: https://rspo.org/ (accessed on 10 September 2018).

31. Andario, P. The Soy Moratorium, 10 years on: How One Commitment is Stopping Amazon Destruction. Available online: https:/ / www.greenpeace.org/archive-international/en/news/Blogs/makingwaves/the-soymoratorium-10-year-anniversary-stopping-amazon-destruction/blog/57127/ (accessed on 10 September 2018). 
32. Haupt, F.; Streck, C.; Bakhtary, H.; Behm, K.; Kroeger, A.; Schulte, I. Zero-Deforestation Commodity Supply Chains by 2020: Are We on Track? Available online: https://climatefocus.com/sites/default/ files / 20180123\%20Supply\%20Chain\%20Efforts\%20-\%20Are\%20We\%20On\%20Track.pdf.pdf (accessed on 10 August 2018).

33. Panlasigui, S.; Rico-Straffon, J.; Swenson, J.; Loucks, C.J.; Pfaff, A. Early Days in the Certification of Logging Concessions: Estimating FSC's Deforestation Impact in Peru \& Cameroon. Available online: http://sites. nicholasinstitute.duke.edu/environmentaleconomics / files/2015/08/WP-EE-15-05-FULL-PDF.pdf (accessed on 13 August 2018).

34. Shah, V. Amnesty International Finds Human Rights Abuses in Wilmar Supply Chain. Available online: http:/ / www.eco-business.com/news/amnesty-international-finds-human-rights-abuses-in-wilmarsupply-chain/ (accessed on 13 August 2018).

35. Gibbs, H.K.; Rausch, L.; Munger, J.; Schelly, I.; Morton, D.C.; Noojipady, P.; Soares-Filho, P.; Barreto, P.; Walker, N.F. Brazil's soy moratorium. Science 2015, 347, 377-378. [CrossRef] [PubMed]

36. Meyer, C.; Lujan, B. Local government must lead at jurisdictional levels. Eur. Trop. For. Res. Netw. 2017, 58, 214-219.

37. Fishman, A.; Oliveira, E.; Gamble, L. Tackling Deforestation through a Jurisdictional Approach: Lessons from the Field. Available online: https:/ / c402277.ssl.cf1.rackcdn.com/publications/1146/files/original/ wwf_ja_brasilia_final_exec_sum_w_cover.pdf?1520454599 (accessed on 13 August 2018).

38. Meyer, C.; Miller, D. Zero deforestation zones: The case for linking deforestation-free supply chain initiatives and jurisdictional REDD+. J. Sustain. For. 2015, 36, 559-580. [CrossRef]

39. REDD Early Movers-Tools and Instruments. Available online: https://www.giz.de/en/worldwide/33356. html (accessed on 1 October 2018).

40. Anair, D.; Mahmassani, A. Cattle, Cleared Forests, and Climate Change: Scoring America's Top Brands on Their Deforestation-Free Beef Commitments and Practices. Available online: https:/ /www.ucsusa.org/sites/default/ files/attach/2016/09/ucs-cattle-cleared-forests-climate-change-2016.pdf (accessed on 13 August 2018).

41. United Nations Framework Convention on Climate Change. REDD+ Web Platform, Lima Info Hub, Brazil Country Overview. Available online: https://redd.unfccc.int/submissions.html?country=bra (accessed on 21 September 2018).

42. Legislação Estadual-Mato Grosso. Criar o Sistema Estadual de Redução de Emissões por Desmatamento e Degradação Florestal, Conservação, Manejo Florestal Sustentável e Aumento dos Estoques de Carbono Florestal—REDD+ no Estado de Mato Grosso e dá outras providências. Available online: https://www. legisweb.com.br/legislacao/?id=249723 (accessed on 21 September 2018).

43. Forest Trends, Ecosystem Marketplace. Big REDD Week for Two Brazilian States. Available online: https: / / www.forest-trends.org/ecosystem_marketplace/big-redd-week-for-two-brazilian-states/ (accessed on 21 September 2018).

44. Produzir, Conservar, Incluir. Available online: http:/ / pci.mt.gov.br/ (accessed on 1 October 2018).

45. Estratégia Produzir, Conservar, e Incluir (PCI) em Mato Grosso. Bases Para o Monitoramento Das Metas. Governo de Mato Grosso. Available online: https://produceprotectplatform.com/img/matogrosso/ docs /Bases\%20para\%20o\%20Monitoramento\%20das\%20Metas\%20da\%20PCI_BR-EN.pdf (accessed on 21 September 2018).

46. Global Forest Watch. Available online: https://www.globalforestwatch.org/ (accessed on 21 September 2018).

47. Heilmayr, R.; Lambin, E.F. Impacts of nonstate, market-driven governance on Chilean forests. Proc. Natl. Acad. Sci. USA 2016, 113, 2910-2915. [CrossRef] [PubMed]

(C) 2018 by the authors. Licensee MDPI, Basel, Switzerland. This article is an open access article distributed under the terms and conditions of the Creative Commons Attribution (CC BY) license (http:/ / creativecommons.org/licenses/by/4.0/). 